\title{
Drying Lakes: A Review on the Applied Restoration Strategies and Health Conditions in Contiguous Areas
}

\author{
Kamshat Tussupova *, Anchita, Peder Hjorth ${ }^{(1)}$ and Mojtaba Moravej \\ Division of Water Resources Engineering, Lund University, Box 118, SE-22100 Lund, Sweden; \\ an4347cc-s@student.lu.se (A.); peder.hjorth@tvrl.lth.se (P.H.); mo8823mo-s@student.lu.se (M.M.) \\ * Correspondence: kamshat.tussupova@tvrl.lth.se; Tel.: +46-46-222-81-01
}

Received: 12 December 2019; Accepted: 22 February 2020; Published: 9 March 2020

check for updates

\begin{abstract}
Decrease of saline lakes, which comprise $44 \%$ of all available lake water, is a major concern. It additionally accelerates the desertification process of the region. Thus, various countries have taken different actions in protecting their lake water levels. The aim of this paper is to assess different strategies directed to tackle the decreased lake water levels in Lake Urmia and the Aral Sea, which split into the North Aral Sea and South Aral Sea. These are among the world's largest and fastest drying saline lakes observed in the past 50 years and have both reduced to $10 \%$ of their original size. The paper presents a thorough review of academic reports, official documents, and databases. Although the dry-up of a lake is a natural process, it has been sped up by human interventions in the hydrological cycle. Dust storms (strong winds) cause problems in the surroundings. In the case of the Aral Sea, they transmit the pollutants from the dry lake bed causing severe health issues. Various strategies were implemented to manage the socio-economic conditions caused due to the drying of lakes. The strategy implemented for the North Aral Sea was to restore the lake by reducing the water withdrawals from the Syr Darya river, which lead to increased water inflow to the sea. The suggested strategy for Lake Urmia was to restore the lake by water transfer activities from various water sources. These projects have not yet been realized. The strategy implemented for the South Aral Sea was to use a dry lake bed to diversify the economy by oil and mineral extraction along with developing a tourist industry based on the considerable interest to come and observe an ecological disaster of such monumental proportions. These findings show that there is no common best solution for this type of problem. The best fit depends on the local context and it is strongly path-dependent.
\end{abstract}

Keywords: drying saline lake; health impacts; saline lake restoration; Aral Sea; Lake Urmia; restoration strategies

\section{Introduction}

\subsection{Drying Saline Lakes in the World-A Brief Presentation}

Saline lakes are endorheic lakes representing $44 \%$ of the volume and $23 \%$ of the area among all the lakes on earth [1]. Saline lakes are generally confined to arid and semi-arid regions in various countries [2]. Due to anthropogenic activities and induced climatic changes, many lakes in different parts of the world dry up rapidly as shown in Figure 1. 


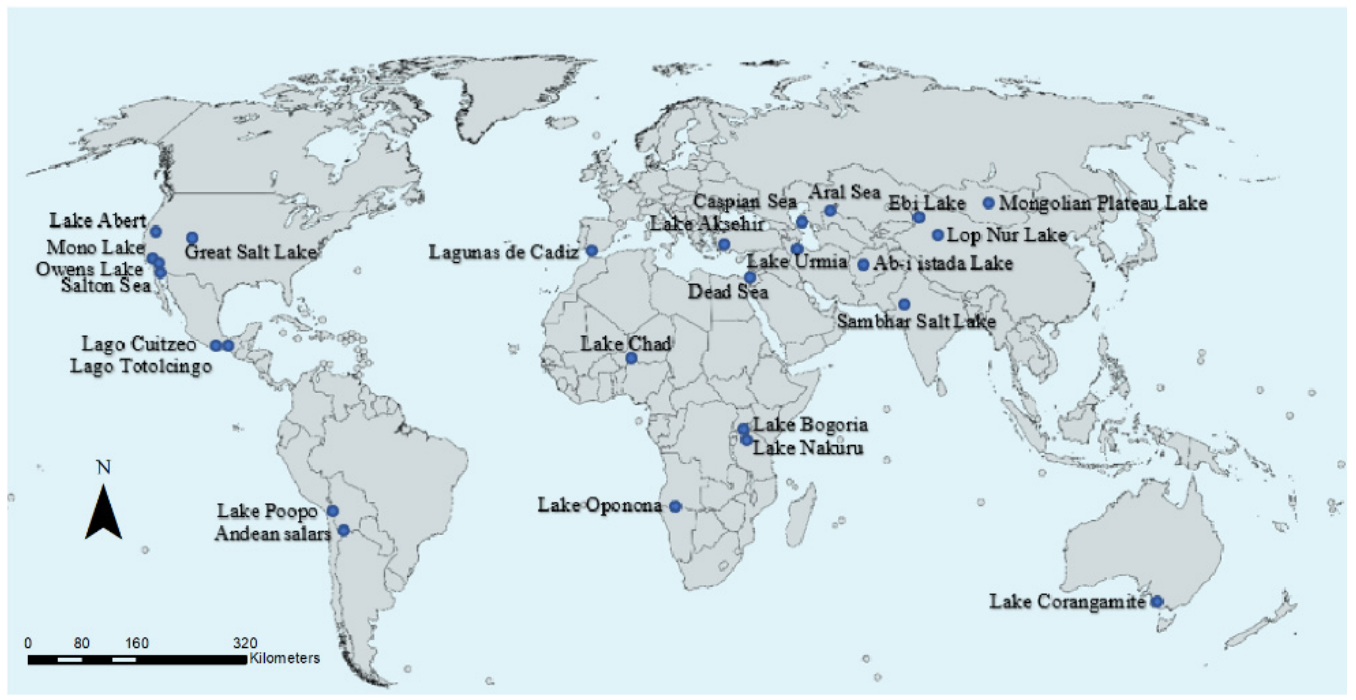

Figure 1. Geographical representation of prominent saline lakes around the world

Drying of a lake causes problems and those of saline lakes foster the worst problems. The reduction in the water-filled area exposes a part of the former lake bottom covered by salt-crusts that are rich in various minerals like sodium chloride, magnesium, calcium, sulphates, borate, lithium, and potassium [2]. These minerals are profitable in certain cases. For instance, minerals from Lake Munclin (Sahara Desert) and the Dead Sea act as fertilizer, salts from Lake Minchin (Salar de Uyuni salt pan) in Bolivia are extracted for table salt and lithium, salt from Bristol Lake in California is extracted for industry and food products $[3,4]$, and salts from the dry lake bed of Lake Zuni are harvested for medicines [5-7]. However, exposed lake beds can also create a public health hazard. Salts from the salt-crust are spread by sand and dust storms. Sand and dust storms usually occur when strong winds lift large amounts of sand and dust from bare, dry soils into the atmosphere [8] causing an increase in respiratory problems (asthma attacks), lung diseases, and related infections. Additionally, a lowered water surface disturbs the ecosystem of a lake; it partly drains the deltas of the rivers supplying the water to the lake. This may affect both the natural ecosystems and the natural environment. In the case of large saline lakes, the number of people that are negatively affected will be quite large. Consequently, there will be a strong pressure on the government to act.

Henceforth, policymakers feel obliged to try to design strategies to restore lake levels, or to eliminate or alleviate the problems one way or the other. This research aims at assessing the health and environmental effects and the efforts made by governments to save drying saline lakes based on the case studies of the Aral Sea and Lake Urmia. As the drying process divided the Aral Sea into two lakes, one in Kazakhstan, and one in Uzbekistan, we have three different cases.

The governments of Uzbekistan, Kazakhstan, and Iran took different approaches towards the identical situation of drying saline lakes.

\subsection{Lake Drying Processes}

Rivers, groundwater, and precipitation recharge the lakes. Since the saline lakes are endorheic, evaporation is the only means of outflow. A lake's water level is said to be self-sustaining when the inflow and outflow are in balance. As observed in the past 50-60 years, the water inflow to several great saline lakes, like the Owens Lake, Lake Urmia, Aral Sea, and the Great Salt Lake in Utah has been decreasing, breaking the balance, and resulting in the reduction of each lake's water level [1].

Anthropogenic activities contribute greatly to the lowering of the water level. According to studies [1] conducted in the late 19th century and the early 20th century, many lakes including the ones mentioned above were characterized as having fluctuating water levels. The enormous amount of 
water diverted from surface and groundwater resources for urbanization, industrial, and agricultural uses resulted in the reduction of water levels $[9,10]$.

The biodiversity in saline lakes is affected by the higher level of mineralization. A reduction of the water level also reduces the water-covered areas exposing the dry salt-rich bottom of a lake to the atmosphere. Dust storms carry these salts from dry lake beds and spread it to nearby regions.

The population living in the vicinity of these drying lakes suffers from several health disorders $[1,11,12]$. In order to determine the relationship between the drying of the saline lakes and the prevailing health issues, this research draws on numerous studies regarding the health of the population living in the Aral Sea region that have been conducted in the past.

\subsection{Data and Methods}

The primary research strategy used was literature review. Online open-source materials and other materials with permission were used for the literature review. These include results from search engines like Google Scholar, LUBsearch, PubMed, ResearchGate, ScienceDirect, Scopus, Springer, and Tandfonline. Reports by the World Bank and databases from the Food and Agriculture Organization (FAO) and Central Asia Water (CAWater) were also considered. Relevant official government records, magazines, and newspaper articles were also considered for this study. It is to be noted that the data are restricted to scientific publications in Russian, Persian, and English languages only. Keywords used to scout the information for the review were: "Aral Sea and health issues", "Restoration of lake", "Health in Kazakhstan", "Health in Uzbekistan", "Aral Sea Health", "Aral Sea Kazakhstan", "Aral Sea Uzbekistan", "Urmia lake restoration program", "Drying of a lake", and "Aral Sea".

An extensive review of the published case studies on the restoration expenses of the Aral Sea and Lake Urmia was performed. The Aral Sea and Lake Urmia are among the fastest drying saline lakes observed in the past 50 years [13]. These two lakes are saline by nature and have reduced by $90 \%$ of their former area over the last $40-50$ years [14,15].

\subsection{Location of the Drying Saline Lakes}

\subsubsection{Lake Urmia Basin}

The Lake Urmia Basin (LUB) which encloses Lake Urmia is located in northeast Iran ( $37^{\circ} 41^{\prime} 59.99^{\prime \prime} \mathrm{N}$, $45^{\circ} 18^{\prime} 60^{\prime \prime}$ E). The lake basin is shared between the provinces of West Azerbaijan, East Azerbaijan, and Kurdistan as shown in Figure 2. LUB has a total area of $51,331 \mathrm{~km}^{2}$ of which $4750-6100 \mathrm{~km}^{2}$ is was occupied by Lake Urmia. The total volume of the lake was $25-27 \mathrm{~km}^{3}$. It has had a maximum depth of $16 \mathrm{~m}$ and average depth of $6 \mathrm{~m}$. It is fed by 60 rivers of which Zarrieh Rud and Simineh Rud contribute the highest flow to the lake [16-18]. The lake originally contained 102 islands that used to attract migratory birds. Lake Urmia was declared as a National Park and a UNESCO Biosphere Reserve. There were five Ramsar sites in the basin-Lake Urmia and four satellite wetlands-and nine globally important bird areas. The lake is the main habitat for the endemic Iranian brine shrimp, Artemia urmiana, and is a protected aquatic environment [19].

\subsubsection{Aral Sea Basin}

The Aral Sea Basin (ASB) which encompasses the Aral Sea, is shared between five countries: Kazakhstan, Kyrgyzstan, Tajikistan, Turkmenistan, and Uzbekistan. The ASB is mainly fed by two main tributaries: the Amu Darya from the North and Syr Darya from the East, as shown in Figure 3 [21].

The Aral Sea was once the fourth largest lake in the world and the largest saline endorheic drainage basin in Central Asia. The total area of the Aral Sea in 1960 was $68,478 \mathrm{~km}^{2}$ with a water capacity of $1093 \mathrm{~km}^{3}$. Since then it has drastically reduced due to diminishing water inflow [22]. The water level decreased from $53.40 \mathrm{~m}$ to $41.02 \mathrm{~m}$ during the period 1960-1986 [22]. In 1986, the Kokaral Desert was formed which separated the Aral Sea into the North Aral Sea (NAS) and South Aral Sea (SAS) [23]. 


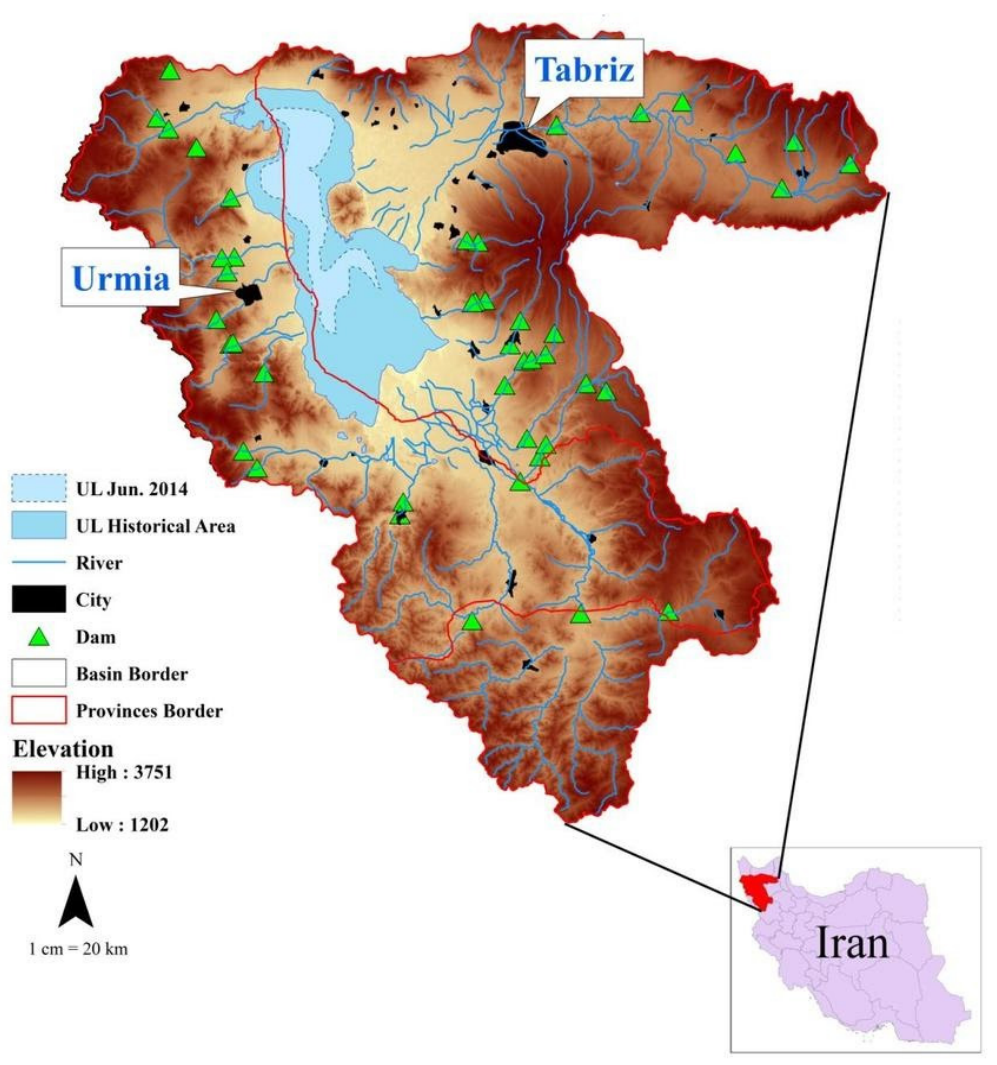

Figure 2. Geographical representation of Lake Urmia Basin (Source: edited from [20]).

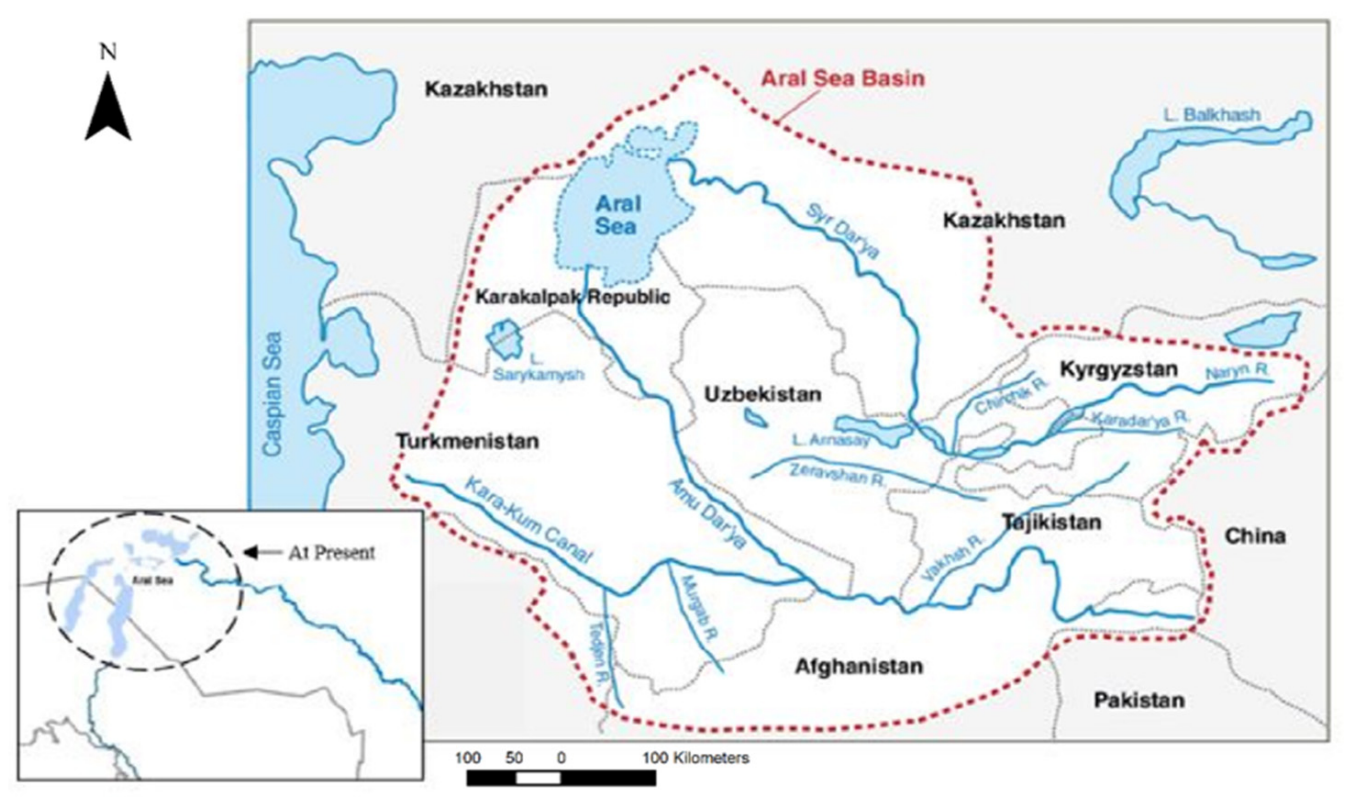

Figure 3. Geographical representation of the Aral Sea Basin. Blue lines indicate tributaries of Amu Darya and Syr Darya. Red dotted lines indicate the Aral Sea Basin. (Source: modified from [24,25]).

The North Aral Sea belongs to Kazakhstan $\left(46^{\circ} 48^{\prime}\right.$ N, $61^{\circ} 40^{\prime}$ E) and had a surface area of $5992 \mathrm{~km}^{2}$, with a water volume of $80 \mathrm{~km}^{3}$, a maximum depth of $29 \mathrm{~m}$, and an average depth of $13.3 \mathrm{~m}$. The NAS is fed by the Syr Darya river which is the confluence of Naryn and Kara-Darya rivers in the Feraghan Valley. It is the second-longest river in Central Asia and reaches the NAS after traveling $2212 \mathrm{~km}$ through the Feraghan Valley. Along this course, Syr Darya receives water from seven rivers, namely 
the Ohangaron and Chirchiq in Uzbekistan, and the Arys, Badam, Boroldai, Bungun, and Keles in Kazakhstan [21].

The South Aral Sea belongs to Uzbekistan $\left(45^{\circ} 00^{\prime} \mathrm{N}, 60^{\circ} 00^{\prime} \mathrm{E}\right)$ and had a surface area of $60,000 \mathrm{~km}^{2}$, with a water volume of $984 \mathrm{~km}^{3}$. The SAS was fed by the Amu Darya tributary, which is the confluence of the Pyanj and Vaksh rivers. It is the largest river in Central Asia and travels $2550 \mathrm{~km}$ from the place of confluence until it reaches the SAS. Along this course, Amu Darya receives water from four rivers, namely Kunduz (Afghanistan), Kafirnigan (Tajikistan), Sherabad (Uzbekistan), and Surkhandarya (Uzbekistan). The SAS has further split into the East and West Aral Seas with a surface area of $46,466 \mathrm{~km}^{2}$ and 13,628 $\mathrm{km}^{2}$, respectively. The East Aral Sea was shallow with a maximum depth of $28 \mathrm{~m}$ and an average depth of $14.7 \mathrm{~m}$, while the West Aral Sea was deeper with a maximum depth of $69 \mathrm{~m}$ and an average depth of $22.2 \mathrm{~m}$ [21].

\section{Drying Saline Lakes and Related Health Effects}

The drying of saline lakes leads to an increase in the exposure of the dry lake bed. The dry lake bed forms a desert which acts as an active particle emission area. Particles can be dust, salt, or pollutants like heavy metals and pesticides. These particles are spread by dust storms causing different health issues like burning eyes, skin irritation, throat irritation, coughing, and respiratory problems including asthma.

According to investigations [26], drying of saline lakes causes respiratory problems, cardiovascular issues, cancer, and DNA changes in the body that may lead to disabilities. The health issues related to the drying up of a lake are experienced nationally and internationally, and include Owens Lake in California, the Great Salt Lake in Utah, Lake Urmia in Iran, and the Aral Sea in Central Asia. The severity of the health issues depends on the degree of exposure of the dry lakebed. For instance, Owens Lake and Mono Lake have a significant level of public health issues in the area around the desiccated lakebed, but they are identified as being less problematic than health issues in the Aral Sea region [27].

Numerous studies were conducted by comparing the local clinical registry, cross-sectional studies, and case-control studies in the Aral region to find the correlation between the declining water level and the deteriorating health conditions of the population living around the Aral Sea. According to the studies, there was no strong relationship found between the dust storms due to drying of the lake and the respiratory issues in the region [28,29]; but Aral lake bed contains heavy metals and pollutants such as persistent organic pollutants (POPs), chemical pesticides like dichlorodiphenyltrichloroethane (DDT), and waste from manufacturing processes, like polychlorinated biphenyl (PCB), which is found in runoff from agriculture and industries [30,31].

According to studies, these pollutants have caused cancer, disability, mortality, nervous and reproductive health problems. Toxic substances such as lead, nickel, and chromium cause nervous disorders; high rates of woman, infant, and perinatal mortality could be due to improper diet or malnutrition. PCB, DDT, 2,3,7,8-tetrachlorodibenzpara-dioxin (TCDD), and other toxic chemicals were present in children's blood, breast milk, urine, and food products [32-36]. Disabilities and malignant neoplasm $[37,38]$ were investigated in the Aral region; results found that the inhalation and oral intake of metals like nickel, cadmium, arsenic, selenium, mercury, manganese, phosphate, nitrate, copper, cobalt, and chromium might have led to the incidence of cancer among the population of the Aral Sea region.

However, there is a high degree of variance in the statistics provided by the various health studies conducted in this region. Moreover, the official health records maintained by the government do not match with the data collected by the studies [39]. The health statistics vary to a considerable degree based on the reference chosen. All these associated variabilities make it difficult to draw a strong conclusion about the adverse health effects of the drying lakes in general. 
There is no clear conclusion that the drying Aral Sea and its associated dust storms are the prime reason for the deteriorating health conditions. However, the dust storms contributed to the health issues by spreading the pollutants across the Aral Sea region. Thus, the pollutants seem to be the primary cause of these diseases. In the absence of pollutants, the dust storms would have been less harmful. Conducting scientific cohort studies as opposed to the cross-sectional studies reported would help identify the specific causes of the health issues around the Aral Sea.

\section{Restoration of Drying Lake Urmia and Aral Sea}

This section presents and discusses the three different approaches taken by Kazakhstan, Uzbekistan, and Iranian governments, respectively, towards the common issue of a drying saline lake. The North Aral Sea was restored by the Kazakhstan government with the implementation of the SYNAS (Syr Darya Control and Northern Aral Sea) project that aided in increasing the lake's water level. The Iranian government is making several proposals on actions to restore Lake Urmia by means of water transfer activities. The South Aral Sea under Uzbekistan government was not restored but rather used to diversify the economy by means of oil and mineral extraction from the dry lake beds.

The Northern Aral Sea was restored by reducing the water withdrawal from upstream rivers under supervision of the Kazakhstan government. The Southern Aral Sea was left without serious plans of restoration as the focus was on direct relief for the population living close to the lake, and the dry lake beds were used for oil and mineral extraction under the Uzbekistan government. Lake Urmia may be restored by water transfer activities from neighboring water sources under the Iranian government. Analyzing the issue from three different perspectives could help understand why and how different kinds of arguments come to play in finding a remedy to the problem of a drying saline lake.

\subsection{Lake Urmia and Restoration Efforts}

Lake Urmia started shrinking at a rapid rate in 1995 as shown in Figure 4a,b. It is difficult to establish what happened in such a varying landscape as that of the Lake Urmia Basin. For example, the mean annual precipitation varies between 300 and $400 \mathrm{~mm}$, and the mean temperature varies between 6.8 and $14.8^{\circ} \mathrm{C}$ [40]. We used the data provided by the Urmia Lake Restoration Project (ULRP) as we believe it represents some consensus: A hundred-year plot of the water surface level shows that it fluctuated around $1274 \mathrm{~m}$ a.s.l. until the early 1960s when it started to increase until the maximum level; $1278.1 \mathrm{~m}$ a.s.l. was reached in 1995 . Then, it began an almost linear decrease until it leveled off somewhat in 2002, and then reached a minimum of $1270.06 \mathrm{~m}$ a.s.l. in 2015 [41].

Since 1975, the area of cultivated land within the basin tripled. This growth was supported by the development of a considerable number of reservoirs and a large network of irrigation canals. It is also stated that there was a reduction in the long-term annual precipitation at the turn of the century. It is claimed that this dropped from $385.8 \mathrm{~mm}$ during the last half of the 20th century to $316.9 \mathrm{~mm}$ during the beginning of the 21st century. The lake lost $90 \%$ of its area. The area loss has been trending at some $220 \mathrm{~km}^{2}$ per year [42].

There were 107,000 wells in the basin in 2012; this can be compared to 64,400 in 2002 and 88,900 in 2007. Farmers seem to overirrigate, as waterlogging has become a problem. The irrigated area increased linearly from 1978 until 2012 when the trend got stronger. In addition, there is a shockingly large number of examples of unauthorized water pumping from the irrigation canals [42]. One picture on the ULRP homepage shows a stretch of about $200 \mathrm{~m}$, where 15 pumps are in action. The homepage also shows how formerly cultivated lands near the lake have been abandoned and invaded by brush vegetation. The satellite wetlands that have been drained have transformed into salt marshes [42].

According to the United Nations Environmental Program (UNEP, 2012), shrinking of the lake increased the salinity, which has impacted the lake ecosystem; in addition, it has affected the local agriculture and livelihoods as well as regional health and tourism [43]. 


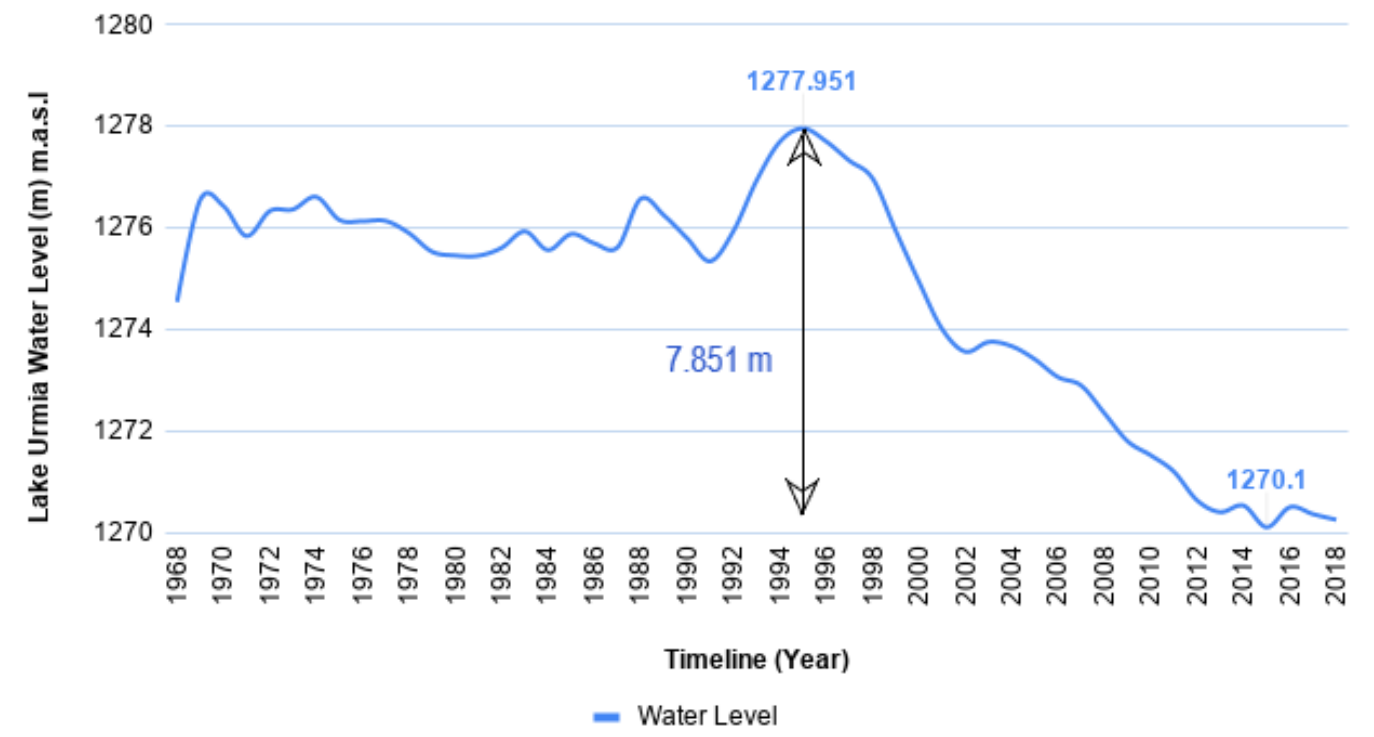

(a)
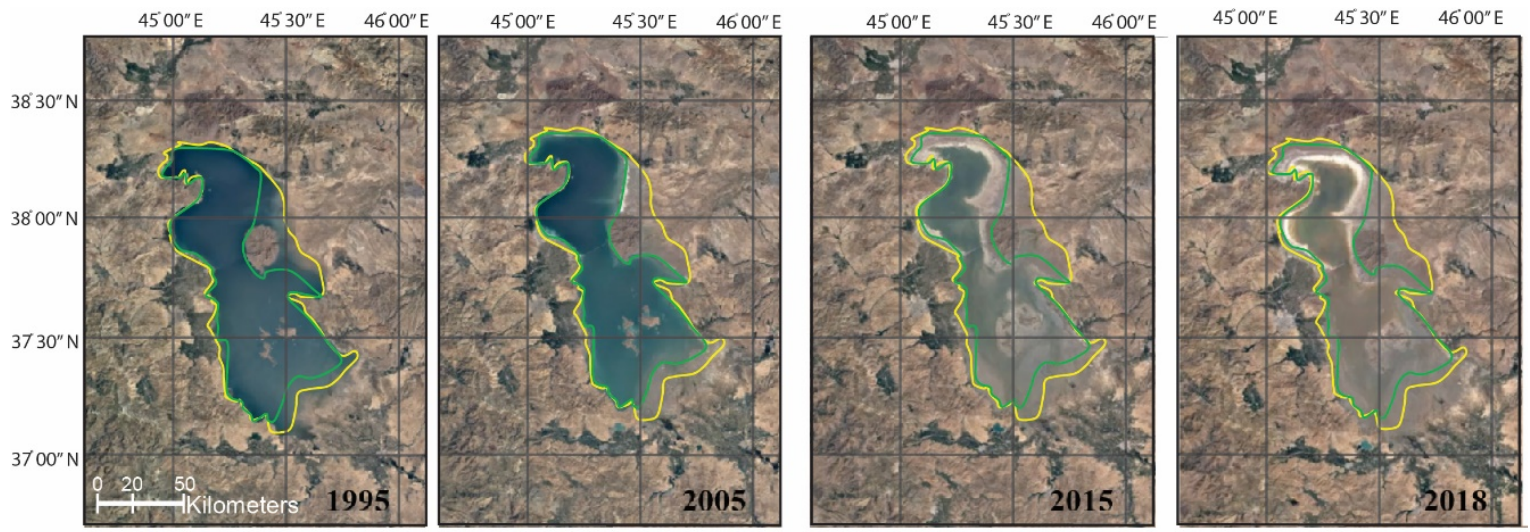

(b)

Figure 4. (a) Water level of Lake Urmia for the period 1966-2018. (b)Trend of reduction in the shoreline of Lake Urmia. Yellow and green lines represent shorelines in 1995 and water level $1274.1 \mathrm{~m}$ a.s.l., respectively.

\subsubsection{Urmia Lake Restoration Project (ULRP) Overview}

The ULRP developed a roadmap for actions to be taken to address the problems of the lake and its basin. The roadmap consists of six packages. Among the activities listed are control and reduction of water consumption in the agricultural sector-reduction of $40 \%$ of the water currently allocated to the farmers [44]. This is to be achieved by: the introduction of a direct purchasing system carried out by the Ministry of Energy in a five-year period; efforts to enhance the productivity of the $60 \%$ that still goes to agriculture, with the Ministry of Jihad-e-Agriculture as the lead agency; financial and technical support from the government to boost the change of technology needed to increase the efficiency of remaining water usage [42].

This will require control and reduction of water withdrawal in the LUB. In addition, measures must be undertaken to prevent an increase in water consumption, and an issuing of a ban on new project developments, especially in the agricultural sector. It will also require a focus on making the prevention of unauthorized surface water withdrawal effective. There must also be a stop to new dam construction projects (except Cheraghveis and Shahid Madani dams), stops to new irrigation water networks in the LUB, and an assurance that the storage of water in the Madani Dam reservoir is used 
exclusively for releases to Lake Urmia [42]. Enforcement of the installation of smart water volume counters will be essential to record and monitor withdrawals from wells throughout the LUB. It will also be necessary to ensure adequate coordination with the judiciary in order to facilitate and accelerate the implementation laws concerning illegal wells [42].

There are also actions focusing on the impacts of the shrinking: identification of dust sources and stabilizing them; development and implementation of an ecological protection program in Urmia National Park; identifying effective actions to increase the recharge rate to the lake; assessments of the health, hygienic, social, and environmental problems caused by the Lake Urmia dry up; preparation and implementation of prevention programs, reducing risk and preventing the likelihood of negative effects; launching new programs to promote an increase of alternative employment opportunities and improve livelihoods [42].

It also mentions that there is limited research on how the problems of Lake Urmia are perceived by the people themselves and how this is communicated to the outside world. Although a lot of scientists are aware of this knowledge gap and search for ways to bridge it, the knowledge on how to execute social research is still missing [44].

\subsubsection{Water Transfer Activities}

According to the ULRP program, the operating time is 10 years which is split into three phases [45] as shown in Figure 5:

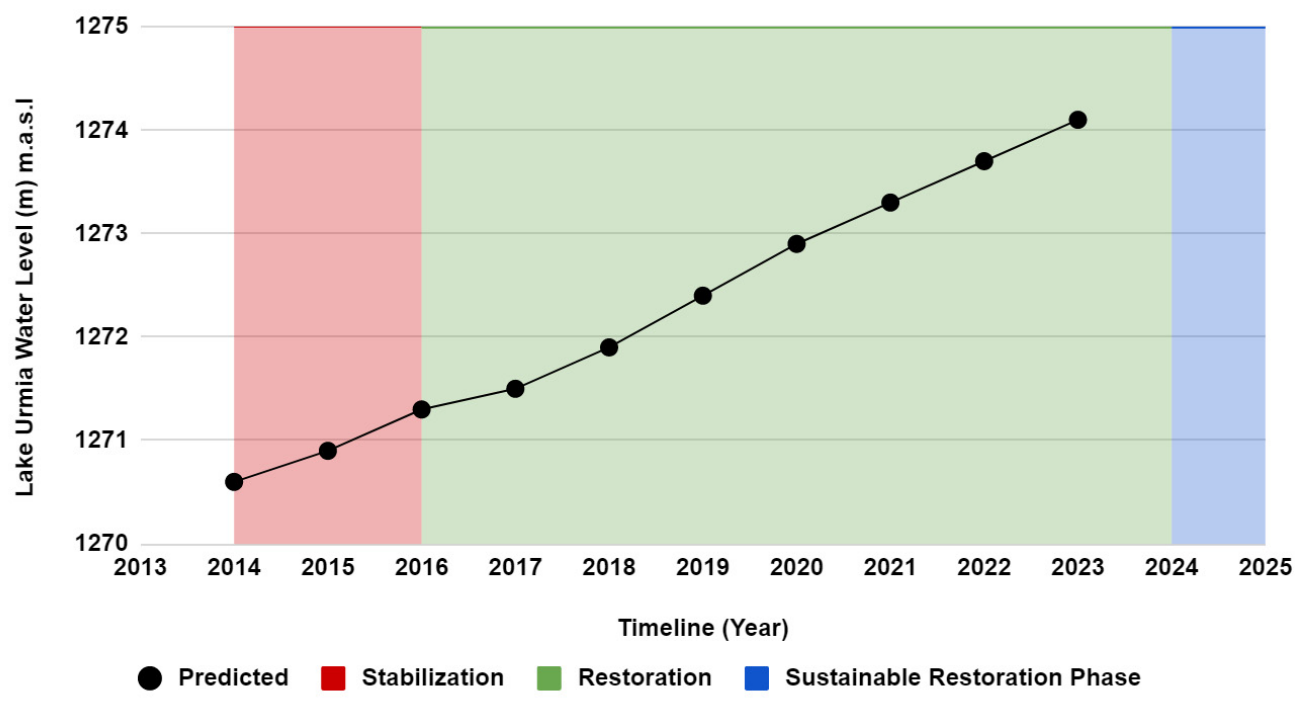

Figure 5. Projected water level for Lake Urmia.

Stabilization phase (2014-2016): implementing projects to reduce lowering of the water level; Restoration phase (2016-2023): implementing solutions to raise the water level; Sustainable restoration phase (2024): ensuring the sustainability of the lake.

In order to increase the water inflow into the lake, the ULRP considers several possibilities:

(1) To use treated wastewater to augment the inflow

(2) To make water transfers from the Zab River

(3) To make water transfers from the Hasanloo Dam

(4) To transfer water from the Aras River

(5) To transfer water from the Caspian Sea

The latter two refer to international water bodies outside of the LUB. Plans to transfer water from the Aras River were met with resistance as they might harm the ecosystem of the Aras River, and jeopardize both the drinking water supply and irrigation currently based on the river [46,47]. 
The water transfer from the Caspian Sea would be extremely costly, due to the very large difference in the altitude $(1316 \mathrm{~m})$ of lake water levels. In addition, some experts claim that the water quality of Caspian Sea could have significant impacts on the ecosystem of Lake Urmia. Furthermore, the Caspian Sea is an ecological reserve, as the ecosystem along its shores is unique [48].

In an attempt to reduce the dust storms, the government of Iran considered the possibility of using treated wastewater to restore the lake and raise the water level. This project had an estimated cost of US $\$ 114.35$ million [49]. The 19 wastewater treatment plants in three provinces under the ULRP have a combined output of $300 \mathrm{MCM}$ (million cubic meters) of treated wastewater annually. Activities involved in transferring treated wastewater to Lake Urmia are constructing the wastewater treatment plant, installing wastewater collection networks, and treating water transfer pipelines [44].

All these projects are very costly. For example, the transfer of treated wastewater has, in addition, met some resistance due to water quality worries as Iranian wastewater treatment plants use a two-step treatment process, as compared to the three-step process used in developed countries. In addition, Iranian treatment plants are frequently overloaded, as there tends to be too few of them. To create a transfer that is large enough, estimated at $300 \mathrm{MCM}$ per year, to have a real impact on Urmia, the wastewater collection networks need to be extended and ensure wider coverage. As the treatment plants already tend to be overloaded, there will be a need to increase the number of plants or to increase the capacity of existing plants. They would also need a quality assurance program, as currently there tend to be frequent causes of malfunctioning, resulting in poorly, or not at all, treated wastewater.

Variations in the inflow of Lake Urmia were estimated under different Intergovernmental Panel on Climate Change (IPCC) scenarios [50]. The study assumed that the minimum annual inflow requirement was $3.6 \times 10^{9} \mathrm{~m}^{3}$, a result obtained by making an estimate based on environmental flow requirements (EFRs). They concluded that the increase of inflow due to a $40 \%$ reduction of the water used in agriculture, is barely enough to sustain a healthy Lake Urmia under the most optimistic climate scenario. For all other scenarios, more drastic measures are needed to ensure an adequate inflow to the lake. Thus, they concluded that an integrated approach to future land-water use planning and climate change adaptation is needed to improve future water security and avoid damage to the lake.

The restoration of drying Lake Urmia is financially demanding. The overall ULRP is estimated to cost US $\$ 1.3$ billion. To better understand the distribution of costs, the Lake Urmia restoration project outline and the respective budget breakdown for the financial year 2015-2016 [44] is expressed in detail in Appendix A. The budget for the year 2015-2016 was US \$626,592,000 (almost half of the estimate in one year of the 10-year project) [49].

\subsection{The Aral Sea and Restoration Efforts}

As the world's fourth-largest lake until the 1960s, the Aral Sea has been well studied for a long time. According to a statement from the Second International Conference on the "Aral Sea Problems" in St. Petersburg 2019, in order to deal wisely with its current predicament, it is necessary to understand that the lake has repeatedly changed its level over the past 10,000 years [51]. This has happened due to natural climate change, repeated displacements of the channels of the rivers feeding the lake, and the redirection of their flow from the Aral Sea to the Caspian Sea or simply to the desert, as well as the development of intensive irrigation systems for agriculture in the basin over the past 4000 years. The current regression, observed since the 1960s, differs from previous ones. Now, irrigation is the dominant regression factor for the first time ever. It has even been more significant than the deviation of the Amu Darya course from the lake. This time, the result amounts to a drying out of the lake, which is the most significant event, at least in the last few thousand years, and will soon become the most significant in the last 10,000 years [51].

To turn the development of the Aral Sea into a remedial path, the statement holds that the most important measure is to ensure more rational use of water resources, as part of the program for the reconstruction of outdated inefficient irrigation systems. There is also a need to consider additional ideas for improving the situation in the Aral Sea and Aral region and develop new innovative projects, 
both for the former sea bottom and for the residual water bodies created as a result of the dramatic drop in water level in the Aral Sea [51].

In 1918, policymakers from the former Soviet Union decided to divert water from the Syr Darya and the Amu Darya for irrigation [52]. This constituted an essential step of their plans to increase cotton production, which they referred to as "white gold". They understood that this would result in a shrinking of the Aral Sea, but they believed that the economic benefits would be more important than the damage to the Aral Sea.

As the Soviet Union started to develop collective agriculture in the 1930s, they also began to construct a large system of irrigation canals. Thereby, crop production rose as the acreage of irrigated areas in Uzbekistan and Turkmenistan increased from 6.4 million acres to 15.9 million acres over two decades, which created employment for millions of people in the region.

However, the shrinking of the Aral Sea did not become noticeable until 1960. By 2005, it had lost more than half of its surface area, exposing nearly $30,000 \mathrm{~km}^{2}$ of the lake bed, and nearly three-quarters of its volume [52]. According to researchers [35], since the 1960s, the water volume reduced by a factor of fourteen and by 1987, the lake split into two separate parts.

Water distribution and sharing were complicated by the collapse of the Soviet Union in 1991, which led to the creation of several new countries, each with separate water policies. A population increase increased the severe water shortage in the area and worsened the environmental disaster. In addition, the river deltas had transformed into deserts, followed by replacement of the original flora with hardier plants. Local climate change became increasingly evident with the disappearance of water; formerly hot, humid regions acquired a cold, dry desert climate.

As human use of river water increased, the composition of lake water changed. According to researchers [35], the salt concentration increased ten-fold and local groundwater reached a salt concentration of $6 \mathrm{~g} / \mathrm{L}$. This is six times higher than the concentration considered safe by the World Health Organization.

An increased frequency of dust storms has created a rate of dust deposition that is among the highest in the world. The authors conclude that local climate change can have negative consequences for human health. The Aral Sea disaster is a case example of the result of short-sighted human exploitation of nature. It is an alarming signal, warning us that all human activities with potential climate effects must be carefully thought through.

The inflow decreased from $20.6 \mathrm{~km}^{3}$ in 2003 to $4.5 \mathrm{~km}^{3}$ in 2010 and direct precipitation onto the lake surface reduced from $9.4 \mathrm{~km}^{3}$ in 1960 to $3 \mathrm{~km}^{3}$ in 2010. The decrease in water levels of the Aral Sea has resulted in a loss of fish species (20 in 1960 against only 5 in 1980) and wild animals (58 heads in 1960 against just 14 in 2000) [53].

In the last half-century, the Aral Sea level has fallen by $16 \mathrm{~m}$ (NAS) and $23 \mathrm{~m}$ (SAS); the water surface decreased by $80 \%$ and the water volume reduced from $1093 \mathrm{~km}^{3}$ to $98.1 \mathrm{~km}^{3}$. The report also claims that the exposed dry seabed reached a surface area of $87,000 \mathrm{~km}^{2}$ in 2010 [53]. As this number is very large, it must be assumed that it includes the areas of the desertified deltas of the Amu Darya and Syr Darya rivers.

The shrinking of the Aral Sea in Central Asia, which was one of the largest inland seas in the world, has become a symbol of what can go wrong when transboundary water is mismanaged [32]. Many consider it to be one of the most dramatic examples of a natural area destroyed by human activities.

Further, it is stated that the profligate use of water for irrigation of cotton monoculture and heavy application of insecticides, pesticides, herbicides, and defoliants has not only resulted in ecological, economic, and social problems for the resident population, but also created a deplorable situation for human health [32]. Apart from the impact on the Aral Sea itself, a real tragedy has emerged due to the associated impacts on the health and well-being of the local population, and the disruption of the ecological balance of the river delta and the region at large.

The sea, which was formerly located in the Soviet Union, is now, after the break-up of the Soviet Union, shared by the Republic of Karakalpakstan in Uzbekistan and Kyzylorda region in Kazakhstan. 
In total, 3.5 million people live around it, including 1.5 million children. Around 1.5 million live in the Uzbekistan part of the affected area, and around $96 \%$ of them are Karakalpaks [32].

Karakalpakstan, an autonomous republic within Uzbekistan, is believed to be the region most affected. This republic is located at the delta of the Amu Darya river, with an area of 165,300 square kilometers (sq. km); for comparison, the area of the Netherlands is only one-fourth of that size [32].

At the time of writing, more than $40,000 \mathrm{~km}^{2}$ of the heavily saline seabed were exposed, and sand and salt were blown out by frequent winds. In addition, some parts, of what was once seabed, were encroached by the rapid growth of wild plants. An increased pace of degradation and desertification of the ecosystems in the deltas of the Amu Darya and Syr Darya was also observed.

According to the report [32], 29,217 tons of toxic pesticides were used in Karakalpakstan during the period 1980-1992. This amounts to an average of 72 kilograms $(\mathrm{kg})$ per hectare, compared with only $4 \mathrm{~kg}$ in Russia and $54 \mathrm{~kg}$ in Uzbekistan. Furthermore, the excessive use of pesticides even in other parts of Uzbekistan makes it quite clear that the region also suffered from polluting upstream activities. In addition, the Vozrozhdeniye Island of this region was used by the Soviet Union as a testing and production site for chemical and biological weapons.

Furthermore, reports of findings of local scientists have shown that the quality of water in the river and drinking water started to deteriorate in the 1960s; since then, the amount of minerals increased in the Amu-Darya river within Karakalpakstan [32]. Among substances discharged into the river were nitrogen, phosphorus, pesticides, copper, arsenic, and phenols. Only in the past 10 years, some 150,000 tons of toxic chemicals contaminated the water. The ensuing change in water quality in the Aral Sea Basin reduced the number of fish in the river and sea and destroyed most of the fauna [32,36].

Unsurprisingly, the long-term impact of environmental pollutants on public health was being increasingly recognized. The population around the Aral Sea suffered from widespread symptoms of poor health. Both the breakdown of the health care infrastructure, since the collapse of the Soviet Union, and the worsening socio-economic and ecological conditions, were assumed to have contributed to the problems [32].

The paper concludes that for the entire Aral Sea Basin, the environmental problems caused by large-scale irrigation and the ensuing salinization of irrigated land and water were the biggest ones. At the time, over $70 \%$ of the irrigated land in Karakalpakstan was affected by salinity, and problems were worsening. Agricultural output had already declined by $30-50 \%$ due to soil salinity, change of the local climate, water deficiency, and reduced labor productivity caused by the widespread health problems [32].

As the government of Uzbekistan has chosen not to address the water issues in the ASB, the problems around the SAS continue to grow stronger. By now, the Amu Darya runs dry before it reaches the SAS. Thus, the eastern part of it is only recharged by groundwater flow.

\subsubsection{Action Taken for Restoration of the Northern Aral Sea}

During the period 1960-1986, the water level of the Aral Sea dropped from $53.40 \mathrm{~m}$ to $41.02 \mathrm{~m}$, resulting in a reduction of the shoreline [22] as shown in Figures 6 and 7.

To restore the Aral Sea, heads of the five countries in the Aral Sea Basin introduced the Aral Sea Basin Programme (ASBP) in 1994. The ASBP was funded by the International Fund for Saving the Aral Sea (IFAS) to improve the ecology and socio-economic situation in the Aral Sea Basin [54]. The main funding partners were the United Nations Development Program (UNDP), United Nations Environmental Program (UNEP), World Bank, Asian Development Bank (ADB), Global Environmental Faculty (GEF), European Bank for Reconstruction and Development (EBRD), Technical Aid to the Commonwealth of Independent States (TACIS), Kreditanstalt Fur Wierderaufbau (KFW), German Development Bank, ERA Kuwait, and the United States Agency for International Development (USAID) [54]. 

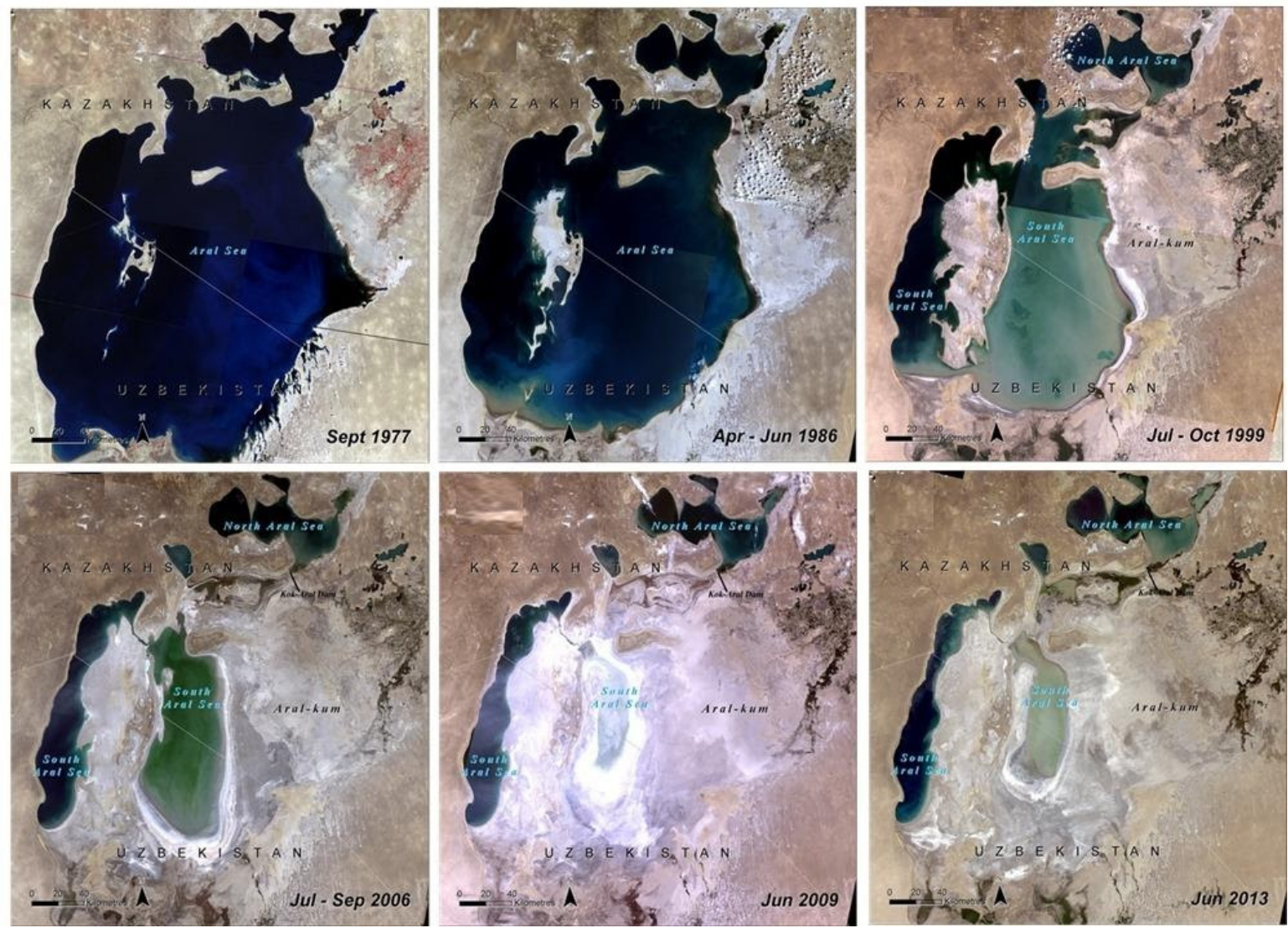

Figure 6. Reduction of the lake area of the Aral Sea, 1977-2013. (Source: modified from [15]).

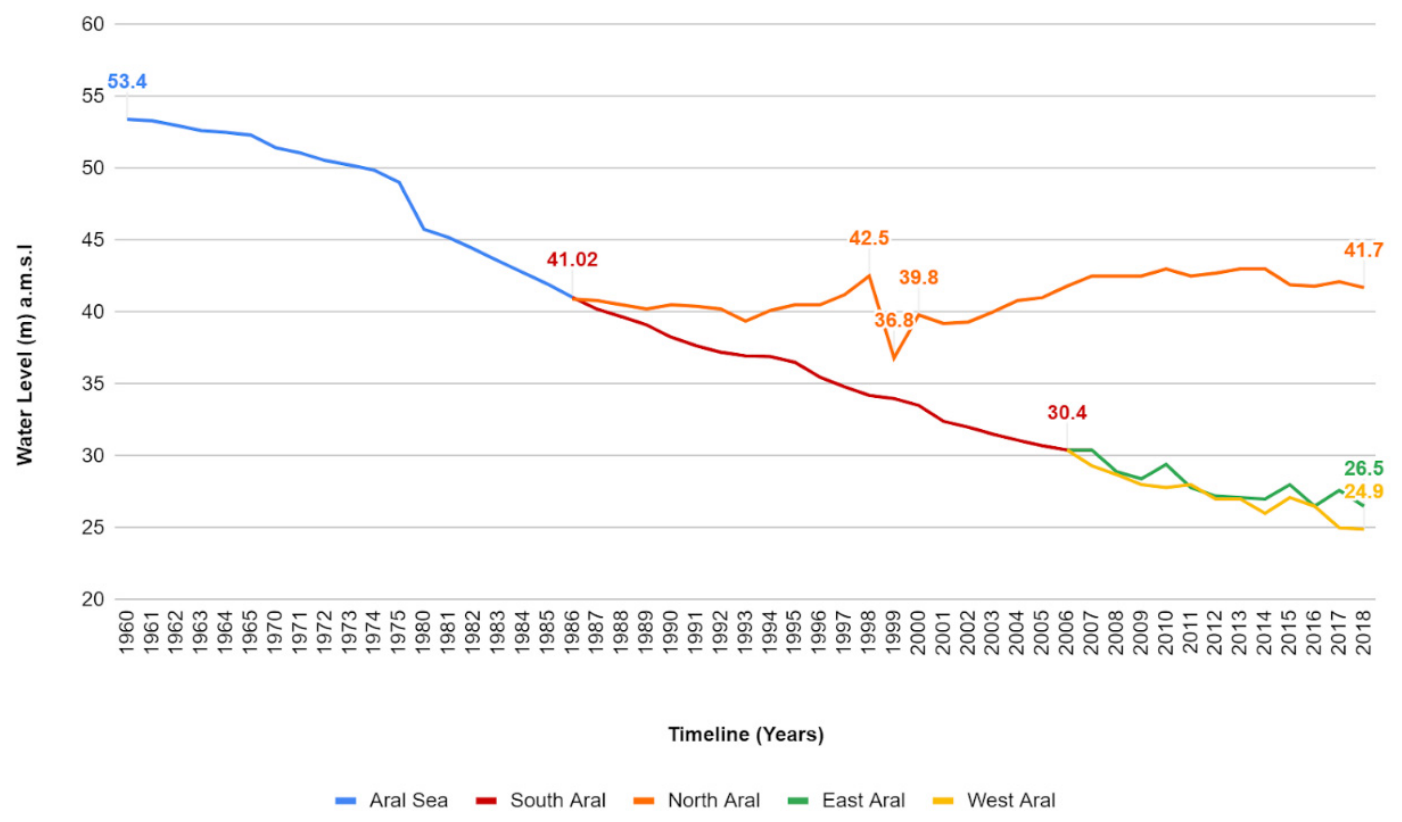

Figure 7. Fluctuation in water level for the Aral Sea, 1960-2018.

The program consisted of 17 activities, each with four components. The total cost for reviving the Aral Sea was estimated to be US $\$ 16$ billion [55]. However, of the countries in the Aral Basin (Kyrgyzstan, Turkmenistan, Tajikistan, Kazakhstan, and Uzbekistan), all except Kazakhstan focused on expanding irrigation. Thus, the program has not yet made any efforts to realize these activities. This review focuses only on "Rehabilitation of the Northern Aral Sea" which was under the project 
"Syr Darya Control and Northern Aral Sea Phase 1 (SYNAS-1)", which was implemented following an agreement between the World Bank and the government of Kazakhstan that tried to restore the part of the lake that was within its territory.

Syr Darya Control and Northern Aral Sea (SYNAS) project did not start from scratch as the local authorities, already in 1992, built an earthen dyke to reduce the flow of water from the NAS to SAS. However, by 1999, the substandard construction could not withstand the increase in water levels and windstorms. A detailed study was carried out on the construction of a new dyke. The new dyke was recommended to have a concrete structure and better hydraulic properties than the existing, which were choked in winter due to ice formation. Finally, the SYNAS-1 project was launched. It lasted from 2001-2008 with an overall cost of US $\$ 83.34$ million. The project had six activities and their respective monetary distribution are shown in Appendix B.

This project had defined objectives [56-58]:

(1) To secure that the North Aral Sea, which will improve the ecology, environment, and biodiversity in the delta, which in turn would improve the health of humans and animals living nearby

(2) Increase agricultural and fishing yields in the region.

The six activities under the project SYNAS are:

- Recuperation of Northern Aral Sea: Construction of earthen dyke made of local fine-grained sand with elevation $44.5 \mathrm{~m}$ a.s.l., length of $13.5 \mathrm{~km}$, width of $2 \mathrm{~m}$, and 9 sluice gates to control the discharge of water [58].

- Improvement of hydraulic regulators for the Syr Darya: Reconstruction of the Aklak weir, Aitek and Karaozek hydraulic regulators to increase the water flow capacity in Syr Darya river, rehabilitation of Kazalinsk and Kyzylorda barrages to improve water availability for irrigation and lakes for fishing activities, and construction of embankments across the river to control floods.

- Rehabilitation of the Chardara Dam: Chardara dam receives a large quantity of water during the winter that is above the storage capacity of the dam. The excess water is diverted to the Arnasi depression in Uzbekistan resulting in flooding problems in Arnasi area. Hence rehabilitation of Kyzylkum irrigation canal, spillway gate and outlet, chutes, and installing instrumentation systems to the dam were prioritized in this activity.

- Restoration of aquatic resources and development of fisheries: This activity aimed at rehabilitating existing freshwater and marine water fish hatcheries to increase trading opportunities and sustainable fishing for sturgeon in the North Aral Sea.

- Monitoring and evaluation: Assessment of socio-economic and environmental impacts of the SYNAS project.

- Project management: Provide financial support and technical advice for the overall project.

\subsubsection{Action Taken for Restoration of the Southern Aral Sea}

The water surface in the Southern Aral Sea (that is divided into two parts: West and East) was $36,960 \mathrm{~km}^{2}$ in 1989 and $6717 \mathrm{~km}^{2}$ in 2011 [55], which indicates that 30,243 km² of dry lake deposit must be restored. Restoring the South Aral Sea, which is greater than the NAS surface area, would require more than US $\$ 83$ million. Hence, the government of Uzbekistan has chosen to focus on alleviating the hardships experienced by the population in the lake area. Thus, it invested in the exploration of oil and gas, salt extraction, plantation of trees on the dry lake bed, and tourism in the SAS. These programs promise economic growth and employment opportunities to the people living in the region.

Uzbekistan is one of the largest producers of cotton in the world, and the government sees cotton growing as a priority. Thus, it made an agreement with the UN to set up a fund, The Multi-Partner Human Security Trust Fund for the Aral Sea region in Uzbekistan (MPHSTF), which does not address the root problem but aims to be transformative and inclusive in its goal of catalyzing and strengthening a multi-sectoral and people-centered response to address the consequences of one of the world's biggest man-made environmental disasters. 
The MPHSTF [59] has developed a strategy for change based on an attack on six interrelated problems that have been found to be decisive:

(1) Environmental insecurity

(2) Economic insecurity

(3) Food insecurity

(4) Health insecurity

(5) Social insecurity

(6) Ineffectiveness of donor assistance

It is stated that this framework was developed based on the results of an independent socio-economic survey conducted in the communities most affected by the environmental disaster.

The Fund primarily aims to strengthen the resilience of the communities in Uzbekistan that have been most affected by the Aral Sea ecological disaster through achieving five specific outcomes:

(1) To reduce the stress on local communities that have emerged due to the deteriorating environmental situation

(2) To increase the employment and income generation opportunities for affected communities

(3) To secure access to affordable and healthy food and clean drinking water for the local communities

(4) To improve the overall health of the local population, and to enable and promote healthy lifestyles

(5) To improve the living conditions of local populations, with a focus on vulnerable groups such as women, children, and youth.

In another program, considerable effort was made toward reducing the nuisance of dust storms by development and afforestation of parts of the dry bottom of SAS. This effort, "Stabilization of the desiccated Aral Sea bottom in Central Asia," [55] is a program that was sponsored and monitored by the German government GTZ in collaboration with Uzbekistan's Forestry Research Institute. The aim of this project was to plant drought-resistant saplings, mainly saxaul-Haloxylon aphyllum to help stabilize the soil. According to the reports, by 2010 and 2015, $2000 \mathrm{~km}^{2}$ and $5000 \mathrm{~km}^{2}$ respectively of self-sustaining forest were observed on the dried lake bed. The increase in plant population was believed to reduce the dust storms. However, no significant changes in the health conditions of the residing population were observed $[55,60]$.

\section{Discussion}

With future prospects in mind, restoring a drying saline lake will be worth the cost if efficient means of sustaining the lake are properly ensured. Investing heavily in restoring the lake gives a certain potential for economic growth in the future. A restored, self-sustaining lake will also benefit biodiversity in the region. This opens a great opportunity for ecotourism. Ecotourism adds significant value to the economy. For example, in 2006 approximately US $\$ 800$ million were spent on wildlife viewing and hunting in Utah [61]. Industry output for the tourism sector in the five counties surrounding the Great Salt Lake (GSL) in Utah was US \$1.56 billion. Bird watching in Utah, most of which takes place in the GSL ecosystem, was valued between US $\$ 99,684,000$ and $\$ 189,463,500$ per year. Duck club members and hunters contributed another US $\$ 61.8$ million in revenue [61]. These revenues from ecotourism demonstrate the potential value of restoring Lake Urmia [61].

On the other hand, a large surface area increases evaporation, demanding more inflow to maintain the water level of a lake, which could be a heavy economic burden if enough profit is not made through the lake. The idea of limiting the water withdrawal from the upstream rivers of Lake Urmia for agricultural would create protests; agriculture is important to the economy and provides employment opportunities around Lake Urmia. Employment in agriculture as a percentage of total employment in Iran stands at $19.2 \%$ and the value-added contribution to gross domestic product (GDP) of Iran stood at $10.8 \%$ in 2015 [62]. 
The acute rise in salinity of the Aral Sea brought about a decline in fishery and other related industries. Fishing, the main economy of the region, was devastated. The population had to find other means of income for survival. The declining health conditions as a result of polluted dust storms added to the misery. Many residents of the Aral Sea region were forced to relocate and diversifying the regional economy for those left was arduous [60]. The SYNAS-1 project ultimately brought the NAS back to life. There was a decrease in salinity and an increase in water levels resulting in a flourishing fish population. The inhabitants, who had employed themselves in service-based industries like transportation, hotels, etc., came back to fishing [60]. With water occupying the drylands and thus mitigating the dust storm issues, the population migrated back to the ASB. A statistical report produced in 2010 shows an economic benefit of US \$13.5 million per year [63] resulting from the restored NAS. Table 1 outlines the observations made from the implementation of SYNAS-1 project.

Table 1. Achievements of the Syr Darya Control and Northern Aral Sea (SYNAS-1) project $[56,57,64]$.

\begin{tabular}{|c|c|}
\hline Category & Benefits \\
\hline Fishing & Increase in yield from 52 tons (2004) to 2650 tons (2009). \\
\hline Agriculture & $\begin{array}{l}\text { Increase in yield of rice from } 58,500 \text { ha (2001) to } 73,300 \text { ha (2009). Sustainable cropping was } \\
\text { practiced in } 150,000 \text { ha land. }\end{array}$ \\
\hline Health & There are reports of improved health conditions, but not enough data to validate this claim. \\
\hline Salinity level & $\begin{array}{l}\text { The water level increased from } 38 \mathrm{~m} \text { to } 42 \mathrm{~m} \text { with salinity drop from } 20 \text { gram per liter } \\
\text { (2001) to } 11 \text { gram per liter (2018). }\end{array}$ \\
\hline $\begin{array}{l}\text { Ecology } \\
\text { Biodiversity } \\
\text { Management } \\
\text { Structure }\end{array}$ & 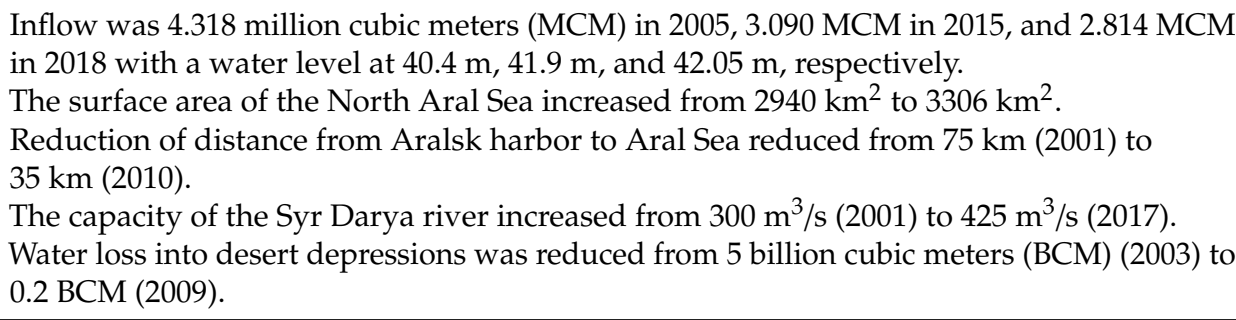 \\
\hline
\end{tabular}

However, there now seems to be relatively frequent instances of illegal fishing during the fish breeding seasons $[65,66]$. This could have severe long-term effects on the sustainability of the fish population. Thus, a check on the usage of resources is crucial for sustenance. This applies to the restored lake. Immediately following the restoration phase, there needs to be a sustaining phase, even if it is perceived to be demanding and costly.

To sustain the restored NAS, an inflow of $6-8 \mathrm{~km}^{3}$ per year is required [67]. Thus, water usage for agricultural practices must be monitored and kept below the allowed limit so that enough water can flow into the NAS. This limitation may constrain the growth of agricultural production and, initially, restrain economic growth of the region. Investing in educating the population and supporting them to diversify the economy might overcome this problem and be a boost to the regional economy.

The three cases were selected because their problems depended on reasons that they have in common, and the resulting impacts have been quite similar, except that Urmia Lake was never polluted to the extent that the Aral Sea was. The main driver was a need for more food to feed a constantly growing population. Thus, the cultivated areas, most of them in need of irrigation, were expanded. This, of course, came at the expense of other uses of water, in our cases the maintenance of the status of lake and delta systems.

In the 1930s, when the Aral Sea Basin was first subject to this kind of development, environmental concerns were beyond the scope of governance. The Urmia case, however, did not really take off until the mid-1990s. By then, environmental issues were vividly discussed for 30 years, at least in developed countries. As Urmia Lake is designated as a protected area, it is reasonable to assume that some of the environmental discussions, and the newly emerged concept of sustainable development, spilled over to Iran. 
The socio-economic contexts are, however, quite different. Three different governments are the main actors. There are important ethnic aspects in the Urmia and South Aral cases. The two Aral cases play out in institutional environments, that have not yet been adequately transformed since the demise of the Soviet Union. The roots of the problems, that have now become extremely evident, were planted by rulers in a now distant Moscow.

As the old saying goes, "Out of sight-out of heart". The North Aral Lake is in the opposite end of the country, as compared to the capital city. The South Aral Sea is located far from the capital. In addition, it is in what is claimed to an independent republic - the Republic of Karakalpakstan. However, as far as we understand, the South Aral case has single-handedly been dealt with by the government of Uzbekistan.

According to Shadkam and colleagues [40], the Urmia Lake basin is in a politically tense region, bordering both Iraq and Turkey. It is also a linguistically and culturally diverse area dominated by two ethnic groups, Azeri Turks and Kurdish, respectively. However, this lake is not that much out of sight, as it is divided into two parts by the highway between Teheran and Tabriz. Thus, citizens of Teheran are reminded, now and then, about the existence of Lake Urmia and its current conditions.

However, there is another issue at play concerning Lake Urmia. For the last decennia, Iran has been deeply involved in the power struggles in the Middle East. Since President George W. Bush named Iran as one of the two support nodes of an "axis of evil", the country has suffered from sanctions imposed on it. Thus, there is a score of issues that compete with Lake Urmia for government attention and financing.

Around all three lakes, there are problems related to the salt crusts on the dry lake bed. Salts are picked up by strong winds and spread around. As these salts settle on agricultural lands, their productivity gets reduced. When human beings get affected by salty dust storms, they may contract various health problems. These kinds of problems have been observed around all the lakes. However, there is not much reliable data on health problems. For Aral Sea problems, one explanation might be that the newly independent states of Kazakhstan and Uzbekistan have not yet managed to fully develop their health care after separation from their old rulers. Concerning Lake Urmia, the ULRP states that it does not yet have adequate capacity to undertake social studies. This might imply that they also may be lacking when it comes to health issues.

Iran is the only country where the government has promised to fully eliminate the problem of a drying lake. The government has stated a full reversal of the problem as the goal. However, thus far, it is the government that has achieved the least.

In Kazakhstan, the government realized that a full reversal would be out of its might. Thus, it has opted for "second best"; to restore the part of the Aral Sea that was inside its territory, together with the drained, and partly desertified, delta of the Syr Darya. This revived the fishery and promoted some recovery of agriculture in the delta region.

In Uzbekistan, cotton growing, and food production were issues of much more concern than the environmental problems related to the Aral Sea. Thus, no action was taken to reverse, or even to stop, the drying of the current South Aral Sea. Instead, the government chose to address some of the problems that the drying caused to the people around the South Aral Sea. As the Aral problem is well known in many parts of the world, the South Aral Sea has been announced as a "must see" exhibit, showing the outcome of one of the world's most spectacular disasters. This has created a booming tourist industry. In a part of the dry bed, there are now installations exploiting oil and gas deposits. This has created job opportunities for the local population. To reduce the nuisance from the salty dust storms, salt tolerant trees have been planted. Reportedly, more than $5000 \mathrm{~km}^{2}$ have been covered by self-sustaining forest. To somewhat help against the change of the local climate that the drying caused, there has also been construction of new housing. 


\section{Conclusions}

Great saline lakes are massive reservoirs of saline water. These lakes undergo natural changes spanning over several millenniums. Although recently, many of these lakes have been drying at an accelerated rate due to anthropogenic activities. The ever-growing population, the increasing demand for water, and an agriculture-centered economy seem to be the customary combination for the desiccation of great saline lakes. The diversion of water for domestic, industrial, and irrigation purposes results in the reduction of inflow to the lakes and a shrinking of them. The Aral Sea and Lake Urmia are examples of such a predicament. The drying saline lakes give rise to health issues and socio-economic problems.

Dust storms hailing from the drying lake beds were speculated to cause health disorders among the population residing near the Aral Sea. However, from the studies conducted on the reported disabilities, no solid evidence was found to show an undeniable connection to the dust storms. On the other hand, perilous pollutants emanating from agriculture and industrial waste disposal were flowing into the lake. These pollutants also play a prominent role in causing the observed diseases and the dust storms provide a medium for their spreading. Therefore, the major cause of the health issues related to dust storms is the pollutants added through anthropogenic activities. Thus, one could conclude that the dust storms, in themselves, may not have any significant effect on human health.

The governments of Uzbekistan, Kazakhstan, and Iran took contrasting approaches towards the identical problem of drying saline lakes. The NAS was restored by Kazakhstan with the implementation of the SYNAS project that served to establish and maintain an increased lake water level. The Iranian government claims to be making consistent efforts to restore Lake Urmia by means of water transfer activities, but the restoration process has failed to keep up with the expected results. The SAS under Uzbekistan government was not restored but rather used to diversify the economy by means of oil and mineral extraction from the dry lake beds. The dry bed has also been transformed into a showcase that attracts visitors from all over the world.

Based on the assessment of the three strategies it can be concluded that restoration is a viable option when the sustenance of the restored lake is safeguarded. In other cases, one could do like Uzbekistan, take a people-centered approach and help those negatively impacted to evade the problems caused by the drying lake. In the Lake Urmia case, it seems difficult to identify any group that is suffering from the drying-up of the lake. In such a case, it is understandable if the government announces a lofty plan, and just waits for the protests to peter out.

Thus, these cases clearly indicate that there is no one solution to the problems of drying saline lakes. The solutions need to fit the local context and also depend on the paths that have led to the problems.

Author Contributions: Conceptualization and methodology, A., K.T., P.H., and M.M.; investigation, A.; writing-draft preparation, A.; writing—review and editing, A., P.H., K.T., and M.M.; supervision, K.T., P.H., and M.M.; visualization, A. and M.M. All authors have read and agreed to the published version of the manuscript.

Funding: This research received no external funding.

Acknowledgments: The authors acknowledge Tshepiso Kwena Lehutjo, Stefani Mazdin, and MD Mostafizur Rahman for collecting the basic information regarding the Lake Urmia Restoration Program.

Conflicts of Interest: The authors declare no conflicts of interest.

\section{Appendix A}

\section{Urmia Lake Restoration Project (ULRP) Activities and Related Expenses}

1. Control and reduction of water consumption in the agricultural sector- $\underline{\mathrm{US} \$ 226,236,000}$

2. Control and reduction in the withdrawal of surface and groundwater in Lake Urmia Basin-US $\$ 16,206,000$

(a) Prevent unauthorized withdrawals from surface water- $\underline{\mathrm{US} \$ 7,455,000}$ 
(b) Installation of smart meters to control water withdrawal from tributary rivers-US $\$ 8,751,000$

3. Initiatives on protection and mitigation of negative impacts- $\underline{\mathrm{US}} \$ 22,201,000$

(a) Identification and stabilization of dust sources-US $\$ 17,534,000$

(b) Study and implementation of Lake Urmia National Park-US \$3,333,000

(c) Preparation and implementation of programs to prevent and reduce health, environmental, and social issues arising from the drying lake-US $\$ 667,000$

(d) Diversifying economy-US $\$ 667,000$

4. Studies and software measures-US $\$ 25,635,000$

(a) Development and implementation of a public awareness program to communicate the importance of lake restoration-US $\$ 7,334,000$

(b) Cadastral mapping of Lake Urmia Basin-US $\$ 8,000,000$

(c) Impact study of Kalantari causeway on Lake Urmia's ecosystem - US \$333,000

(d) Feasibility assessment of Lake Urmia's salts for industrial application-US \$1,333,000

(e) Study of the plans to transfer water to Lake Urmia from the Caspian Sea-US $\$ 467,000$

(f) Monitoring and evaluating implemented projects-US $\$ 6,835,000$

(g) Design and deployment of decision support system- $\underline{\mathrm{US} \$ 667,000}$

(h) Study to reduce evaporation and perform cloud seeding within Lake Urmia Basin-US $\$ 666,000$

5. Facilitate the increase of the water volume entering the Lake throughout structural measures-US $\$ 23,535,000$

(a) Water transfer to Lake Urmia's islands and wetlands through Hasanloo Dam-US $\$ 667,000$

(b) Water transfer through rivers-US $\$ 22,868,000$

6. Water supply from new water resources-US $\$ 312,779,000$

(a) Water transfer from Zab River to Lake Urmia-US $\$ 197,099,000$

(b) Water transfer from wastewater treatment plants-US $\$ 114,347,000$

(c) Research and implementation of water transfer from the Aras River-US $\$ 1,333,000$

\section{Appendix B}

\section{Syr Darya Control and Northern Aral Sea Project (SYNAS) Activities and Related Expenses}

1. Recuperation of Northern Aral Sea-US \$23.19 million

2. Improvement of hydraulic regulators for the Syr Darya-US $\$ 40.95$ million

3. Rehabilitation of the Chardara Dam-US $\$ 14.10$ million

4. Restoration of aquatic resources and development of fisheries-US \$2 million

5. Monitoring and evaluation-US $\$ 1.50$ million

6. Project management-US \$1.60 million

\section{References}

1. Wurtsbaugh, W.A.; Miller, C.; Null, S.E.; DeRose, R.J.; Wilcock, P.; Hahnenberger, M.; Howe, F.; Moore, J. Decline of the World's Saline Lakes. Nat. Geosci. 2017, 10, 816-821. [CrossRef] 
2. Jellison, R.; Williams, W.D.; Timms, B.; Aladin, N.V. Salt Lakes: Values, Threats and Future. In Aquatic Ecosystems: Trends and Global Prospects; Cambridge University Press: Cambridge, UK, 2008; pp. 94-110.

3. Jones, B.F.; Deocampo, D.M. 5.13-Geochemistry of Saline Lakes. In Treatise on Geochemistry; Holland, H.D., Turekian, K.K., Eds.; Pergamon: Oxford, UK, 2003; Volume 5, pp. 393-424.

4. Land Use Data Base (LUDB). The Center for Land Use Interpretation: Bristol Dry Lake, California. Available online: https://clui.org/ludb/site/bristol-dry-lake (accessed on 11 October 2019).

5. Cox, R. Environmental Communication and the Public Sphere, 3rd ed.; Sage publications: London, UK, 2013.

6. Corbin, A. Sacred Land Film Project, Zuni Salt Lake-United States Sacred Land. Available online: https://sacredland.org/zuni-salt-lake-united-states/ (accessed on 11 October 2019).

7. Scurlock, D. From the Rio to the Sierra: An Environmental History of the Middle Rio Grande Basin; General Technical Report RMRS-GTR-5; US Department of Agriculture, Forest Service, Rocky Mountain Research Station: Fort Collins, CO, USA, 1998; Volume 5, p. 440.

8. World Meteorological Organization (WMO). Sand and Dust Storms. Available online: https://public.wmo. int/en/our-mandate/focus-areas/environment/SDS (accessed on 11 October 2019).

9. Moravej, M.; Khalili, K. Hydrological Time Series Analysis and Modelling Using Statistical Tests and Linear Time Series Models (Case Study: West Azerbaijan Province of Iran). Int. J. Hydrol. Sci. Technol. 2015, 5, 349-371. [CrossRef]

10. Moravej, M. Investigating Climate Change Using Ak Stationarity Test in the Lake Urmia Basin. Int. J. Hydrol. Sci. Technol. 2016, 6, 382-407. [CrossRef]

11. Heydari, N.; Jabbari, H. Worldwide Environmental Threats to Salt Lakes. Int. J. Des. Nat. Ecodynamics 2012, 7, 292-299. [CrossRef]

12. Wiggs, G.F.; O’hara, S.L.; Wegerdt, J.; Van Der Meer, J.; Small, I.; Hubbard, R. The Dynamics and Characteristics of Aeolian Dust in Dryland Central Asia: Possible Impacts on Human Exposure and Respiratory Health in the Aral Sea Basin. Geogr. J. 2003, 169, 142-157. [CrossRef]

13. Newton, J. Why Are the World's Lakes Disappearing? Available online: http://www.dailymail.co.uk/travel/ travel_news/article5254133/Why-worlds-lakes-disappearing.html (accessed on 11 October 2019).

14. Fazel, N.; Berndtsson, R.; Uvo, C.B.; Madani, K.; Kløve, B. Regionalization of Precipitation Characteristics in Iran's Lake Urmia Basin. Theor. Appl. Climatol. 2018, 132, 363-373. [CrossRef]

15. Harriman, L.; Chander, A.; Sing, A.; Litswa, E.; Giese, K.; Anthony, M.; Hussain, R.; Giri, T.; Mwangi, T.; Zommers, Z. The Future of the Aral Sea Lies in Transboundary Co-Operation Article Reproduced from United Nations Environment Programme (Unep) Global Environmental Alert Service (Geas). Environ. Dev. 2014, 10, 120-128.

16. Emdadi, A.; Gikas, P.; Farazaki, M.; Emami, Y. Salinity Gradient Energy Potential at the Hyper Saline Urmia Lake-Zarrinehrud River System in Iran. Renew. Energy 2016, 86, 154-162. [CrossRef]

17. Yazdandoost, F.; Khorami, N. Integrated Sediment Transport Modelling for Rivers Feeding Lakes and Wetlands. In Proceedings of the River Sedimentation: Proceedings of the 13th International Symposium on River Sedimentation, Stuttgart, Germany, 19-22 September 2016; p. 112.

18. Chaudhari, S. Modeling and Remote Sensing of Water Storage Change in Lake Urmia Basin, Iran; Michigan State University: East Lansing, MI, USA, 2017.

19. Karbassi, A.; Bidhendi, G.N.; Pejman, A.; Bidhendi, M.E. Environmental Impacts of Desalination on the Ecology of Lake Urmia. J. Great Lakes Res. 2010, 36, 419-424. [CrossRef]

20. Zarghami, M.; AmirRahmani, M. A System Dynamics Approach to Simulate the Restoration Plans for Urmia Lake, Iran. In Optimization and Dynamics with Their Applications; Springer: Berlin/Heidelberg, Germany, 2017; pp. 309-326.

21. Micklin, P. Introduction to the Aral Sea and Its Region. In The Aral Sea; Springer: Berlin/Heidelberg, Germany, 2014; Volume 10178, pp. 15-40.

22. CAWaterInfo. Aral Data. Available online: http://www.cawater-info.net/aral/data/morpho_e.htm (accessed on 11 October 2019).

23. Breckle, S.-W.; Geldyeva, G. Dynamics of the Aral Sea in Geological and Historical Times. In Aralkum- $a$ Man-Made Desert; Springer: Berlin/Heidelberg, Germany, 2012; pp. 13-35.

24. Micklin, P. The Aral Sea Disaster. Ann. Rev. Earth Plan. Sci. 2007, 35, 47-72. [CrossRef]

25. Wegerich, K.; Van Rooijen, D.; Soliev, I.; Mukhamedova, N. Water Security in the Syr Darya Basin. Water 2015, 7, 4657-4684. [CrossRef] 
26. Wurtsbaugh, W.; Miller, C.; Null, S.; Wilcock, P.; Hahnenberger, M.; Howe, F. Impacts of Water Development on Great Salt Lake and the Wasatch Front. Water. Sci. Facul. Pub. 2016, 875.

27. Aron, J.L.; Patz, J. Ecosystem Change and Public Health: A Global Perspective; JHU Press: Baltimore/London, UK, 2001.

28. Kunii, O.; Hashizume, M.; Chiba, M.; Sasaki, S.; Shimoda, T.; Caypil, W.; Dauletbaev, D. Respiratory Symptoms and Pulmonary Function among School-Age Children in the Aral Sea Region. Arch. Environ. Health Int. J. 2003, 58, 676-682. [CrossRef] [PubMed]

29. Bennion, P.; Hubbard, R.; O’Hara, S.; Wiggs, G.; Wegerdt, J.; Lewis, S.; Small, I.; van der Meer, J.; Upshur, R.; Dust, M.s.F.A.S.R.; et al. The Impact of Airborne Dust on Respiratory Health in Children Living in the Aral Sea Region. Int. J. Epidemiol. 2007, 36, 1103-1110. [CrossRef]

30. Zetterström, R. Food Pollutants and Child Health with Special Reference to the Situation in the Aral Sea Region in Kazakhstan. Näringsforskning 1998, 42, 130-135. [CrossRef]

31. Goldman, L.; Tran, N. The Impact of Toxic Substances on the Poor in Developing Countries; World Bank: Washington, DC, USA, 2002.

32. Ataniyazova, O.A. Health and Ecological Consequences of the Aral Sea Crisis. In Proceedings of the 3rd World Water Forum, Regional Cooperation in Shared Water Resources in Central Asia, Kyoto, Japan, 18 March 2003.

33. Ataniyazova, O.; Baumann, R.; Liem, A.; Mukhopadhyay, U.; Vogelaar, E.; Boersma, E. Levels of Certain Metals, Organochlorine Pesticides and Dioxins in Cord Blood, Maternal Blood, Human Milk and Some Commonly Used Nutrients in the Surroundings of the Aral Sea (Karakalpakstan, Republic of Uzbekistan). Acta Paediatr. 2001, 90, 801-808. [CrossRef]

34. Herbst, S. Water, Sanitation, Hygiene and Diarrheal Diseases in the Aral Sea Area (Khorezm, Uzbekistan). Ph.D. Thesis, University of Bonn, Bonn, Germany, 2005.

35. Wæhler, T.A.; Dietrichs, E.S. The Vanishing Aral Sea: Health Consequences of an Environmental Disaster. Tidsskrift for den Norske laegeforening: Tidsskrift for praktisk medicin, ny raekke 2017, 137.

36. Bekturganov, Z.; Tussupova, K.; Berndtsson, R.; Sharapatova, N.; Aryngazin, K.; Zhanasova, M. Water Related Health Problems in Central Asia-A Review. Water 2016, 8, 219. [CrossRef]

37. Sakiev, K.Z.; Battakova, S.B.; Amanbekov, W.; Miyanova, G.; Ponizov, D.A.; Khasenova, A.R.; Kisapov, Z. Methodological Aspects of Assessing the Mental Health of the Popular Area Population; Kyrgyz, P., Arys, S., Atasu, U., Eds.; Karaganda State Medical University: Karaganda, Kazakstan, 2017; pp. 66-87.

38. Sakiev, K. Integrated Approaches in the Management of the Health of the Population of the Area; Ministry of Health and Social Development of the Republic of Kazakhstan, Ed.: Karaganda, Kazakhstan, 2016.

39. Crighton, E.J.; Elliott, S.J.; van der Meer, J.; Small, I.; Upshur, R. Impacts of an Environmental Disaster on Psychosocial Health and Well-Being in Karakalpakstan. Soc. Sci. Med. 2003, 56, 551-567. [CrossRef]

40. Shadkam, S.; Ludwig, F.; van Oel, P.; Kirmit, Ç.; Kabat, P. Impacts of Climate Change and Water Resources Development on the Declining Inflow into Iran's Urmia Lake. J. Great Lakes Res. 2016, 42, 942-952. [CrossRef]

41. Eimanifar, A.; Mohebbi, F. Urmia Lake (Northwest Iran): A Brief Review. Saline Syst. 2007, 3, 5. [CrossRef] [PubMed]

42. Shahbaz, H. Challenges of Urmia Lake and Restoration Program. Available online: http://www.ulrp.ir/wpcontent/uploads/2019/04/Presentation-red.pdf (accessed on 10 January 2020).

43. Pengra, B. The Drying of Iran's Lake Urmia and Its Environmental Consequences; UNEP-GRID, Sioux Falls: Nairobi, Kenya, 2012.

44. Urmia Lake Restoration Program (ULRP). Urmia Lake Restoration Program Brief Report and Projects Outline; Urmia Lake Restoration Program: Tehran, Iran, 2015.

45. Urmia Lake Restoration Program (ULRP). Integrated Program for Sustainable Water Resources Management in Lake Urmia Basin; Urmia Lake Restoration Program steering committee: Urmia, Iran, 2017.

46. Rajabova, S. Experts Warn About Deficiencies of Project to Transfer River Aras Water to Lake Urmia. Available online: https://www.azernews.az/analysis/64617.html (accessed on 23 September 2019).

47. Zaman. Iran's Urmia Recovery Plan: Water Transfer from Aras River. Available online: https://theiranproject.com/ blog/2013/01/26/irans-urmia-recovery-plan-water-transfer-from-aras-river/ (accessed on 23 November 2019).

48. Mamaev, V.; Gugele, B.; Strobel, B.; Taylor, P.; Ritter, M.; Jaoshvili, S. The Caspian Sea. European Environment Agency. Available online: http://www.eea.europa.eu/publications/report_2002_0524_154909/ regional-seasaroundeurope/CaspianSea (accessed on 23 November 2019). 
49. Urmia Lake Restoration Program (ULRP). Urmia Lake Challenges, Actions and the Way Forward; Urmia Lake Restoration Program: Tehran, Iran, 2019.

50. Shadkam, S.; Ludwig, F.; van Vliet, M.T.; Pastor, A.; Kabat, P. Preserving the World Second Largest Hypersaline Lake under Future Irrigation and Climate Change. Sci. Total Environ. 2016, 559, 317-325. [CrossRef]

51. Nikoli, A.d.; Vsil'evich. Aral Sea Problem. In Proceedings of the St. Petersberg 2nd International Conference, St. Petersberg, Russia, 12-15 October 2019.

52. Bennett, K. Disappearance of the Aral Sea. Available online: https://www.wri.org/blog/2008/05/disappearancearal-sea (accessed on 11 November 2019).

53. Gaybullaev, B.; Chen, S.-C.; Gaybullaev, D. Changes in Water Volume of the Aral Sea after 1960. Appl. Water Sci. 2012, 2, 285-291. [CrossRef]

54. Rice, E. Aral Sea Basin Program (Kazakhstan, Kyrgyz Republic, Tajikistan, Turkmenistan and Uzbekistan) Water and Environmental Management Project; Food and agricultural organization; World Bank Group: Rome, Italy, 2012.

55. Micklin, P.; Aladin, N.; Plotnikov, I. The Aral Sea: The Devastation and Partial Rehabilitation of a Great Lake; Springer: Berlin/Heidelberg, Germany, 2014.

56. Raturi, R. Kazakhstan-Syr Darya Control \& Northern Aral Sea Phase I Project; World Bank; World Bank Group: Washington, DC, USA, 2012.

57. Arcadis. Kazakhstan-Syr Darya Control and Northern Aral Sea Project-Environmental Assessment; World Bank; ARCADIS Euroconsult: Arnhem, The Netherlands, 2000.

58. Yildiz, D. How the Aral Sea Will Look Like in Foreseeable Future; World Water Diplomacy \& Science News: Ankara, Turkey, 2019.

59. United Nations Development Programme-Multi Partner Trust Fund (UNDP-MPTF). Un MPTF Human Security Trust Fund for the Aral Sea Region in Uzbekistan. Available online: http://mptf.undp.org/factsheet/ fund/ARL00 (accessed on 10 January 2020).

60. Living Asia. The Sea of Comparing: Comparing the Uzbek and Kazakh Sides of the Aral Sea. Available online: http://livingasia.online/aralsea/uz_kaz (accessed on 11 October 2019).

61. Marden, B.; Micklin, P.; Wurtsbaugh, W. Lake Urmia Crisis and Roadmap for Ecological Restoration of Lake Urmia; United Nations Development Program, Iranian Department of Environment and Kalantari Commission: Tehran, Iran, 2014.

62. UNEP. Lake Urmia: Signs of Recovery. Available online: https://wedocs.unep.org/bitstream/handle/20.500. 11822/22312/Foresight_\%20Brief_\%20004_2017.pdf?sequence=1\&isAllowed=y (accessed on 11 October 2019).

63. World Bank. Implementation Completion and Results Report for Syr Darya Control and Northern Aral Sea Phase-1 Project; World Bank Group: Washington, DC, USA, 2011.

64. IFAS. Modern History of the International Fund for Saving the Aral Sea and Prospects for Further Regional Cooperation. Available online: http://kazaral.org/en/aral-summit-2018-a-new-trend-of-water-cooperationin-central-asia/\# (accessed on 11 October 2019).

65. Wheeler, W. Fish as Property on the Small Aral Sea, Kazakhstan. Leg. Prop. Ownersh. 2017, 4, 203.

66. Warren, M. Once Written Off for Dead, the Aral Sea Is Now Full of Life. Available online: https://www.nationalgeographic.co.uk/environment-and-conservation/2018/03/once-written-deadaral-sea-now-full-life (accessed on 11 October 2019).

67. FAO. Aquastat-Fao's Information System on Water and Agriculture. Available online: http://www.fao.org/ $\mathrm{nr} /$ water/aquastat/basins/aralsea/index.stm (accessed on 11 October 2019).

(C) 2020 by the authors. Licensee MDPI, Basel, Switzerland. This article is an open access article distributed under the terms and conditions of the Creative Commons Attribution (CC BY) license (http://creativecommons.org/licenses/by/4.0/). 